Türkiye Jeoloji Bülteni
Geological Bulletin of Turkey
$63(2020) 329-344$
doi: $10.25288 / \mathrm{tjb} .638029$

\title{
A New Contribution to the (IPC) Bouguer Map of a Gap Area in Mosul and Duhok Region (Iraq)
}

\author{
Marwan Mutib $^{1}$ (D), Maan H. Al-Majid ${ }^{2}$ D, Fadhıl A. Ghaib ${ }^{3} \mathbb{D}$ \\ ${ }^{1}$ Department of Refining and Petroleum Engineering, College of Petroleum and Mining Engineering, \\ University of Mosul, Iraq \\ ${ }^{2}$ Department of Petroleum Reservoir Engineering, College of Petroleum and Mining Engineering, \\ University of Mosul, Iraq \\ ${ }^{3}$ Geology Department, College of Science, Salah al-din University, Iraq
}
• Geliş/Received: 25.10.2019 • • Düzeltilmiş Metin Geliş/Revised Manuscript Received: 07.02.2020 • • Kabul/Accepted: 09.03.2020
• Çevrimiçi Yayın/Available online: 23.03.2020 • Bask1/Printed: 20.06.2020
Araştırma Makalesi/Research Article Türkiye Jeol. Bül./Geol. Bull. Turkey

\begin{abstract}
The purpose of the current study was to complete an important gap within the Bouguer map of Iraq implemented by the Iraq Petroleum Company (IPC). In addition, the collected data were processed with recent gravity concepts and methods to establish a new regional geological image. A total of 868 gravity points were measured and corrected.

The Bouguer anomaly map of the study area was initially drawn up with the parameters and equations used to construct the IPC map. The newly-produced map shows a very strong correlation with the old IPC results. A new Bouguer map of the study area was then constructed using modern parameters and equations. A comparison between the old and new maps illustrates the difference between recent and previous techniques.

The isostatic residual map shows the presence of over-compensated areas close to Chia Gara and Mateen and spreads to the Aqra zone with a negative value of up to $-20 \mathrm{mGal}$. In contrast, there is under-compensation in the southern regions with positive isostatic anomalies of about $80 \mathrm{mGal}$. In the researched area there are zero compensation lines around the larger structures (Chia Gara, Mateen, Mangesh, Aqra, Piris, and Perat). In order to draw up the crustal thickness map, the Moho discontinuity depth was determined using topographic and Bouguer anomaly grids of the study area. In addition, the upper mantle anomalies were calculated by continuing the isostatic residual anomaly to $45 \mathrm{~km}$ upward and then removing the past isostatic residual anomaly, that was continued upward to $35 \mathrm{~km}$. Several qualitative approaches were used to isolate the regional and remaining anomalies to analyze the gravity data, with an optimal upward continuation level of 14 kilometers generated for the large and small maps.
\end{abstract}

Keywords: Gap area, Gravity exploration, Geosoft program, Northern Iraq

\section{INTRODUCTION}

The study area covers approximately $8000 \mathrm{~km}^{2}$ in northern Iraq and is divided into three areas. Firstly, is the Zakho district (about $1000 \mathrm{~km}^{2}$ ) including the area in and around the city of Zakho bounded by longitudes $\left(42^{\circ} 36^{\circ} \mathrm{E}-42^{\circ} 55^{\circ} \mathrm{E}\right)$ and latitudes $\left(36^{\circ} 51^{\prime} \mathrm{N}-37^{\circ} 11^{\prime} \mathrm{N}\right)$. The second is Duhok-Mosul region (about $5250 \mathrm{~km}^{2}$ ) including the area in Duhok and around Duhok and Mosul cities bounded by longitudes $\left(42^{\circ} 55^{\circ} \mathrm{E}-43^{\circ} 34^{`} \mathrm{E}\right)$ and latitudes $\left(36^{\circ} 24^{\circ} \mathrm{N}-37^{\circ} 14^{\prime} \mathrm{N}\right)$. The third is Aqra region (about $1750 \mathrm{~km}^{2}$ ) which includes the area in and around the town of Aqra bounded by longitudes $\left(43^{\circ} 34^{\circ} \mathrm{E}-44^{\circ} 22^{\circ} \mathrm{E}\right)$ and latitudes $\left(36^{\circ} 36^{\circ} \mathrm{N}-36^{\circ} 52^{\circ} \mathrm{N}\right)$. Figure 1 shows the tectonic zones and structural elements of the unstable shelf located in the study regions.

\footnotetext{
*Correspondence / Yazışma: maanalmajid@gmail.com
}

(C) $2020 \mathrm{JMO}$ Her hakkl saklıdır/All rights reserved http://tjb.jmo.org.tr http://dergipark.gov.tr/tjb 


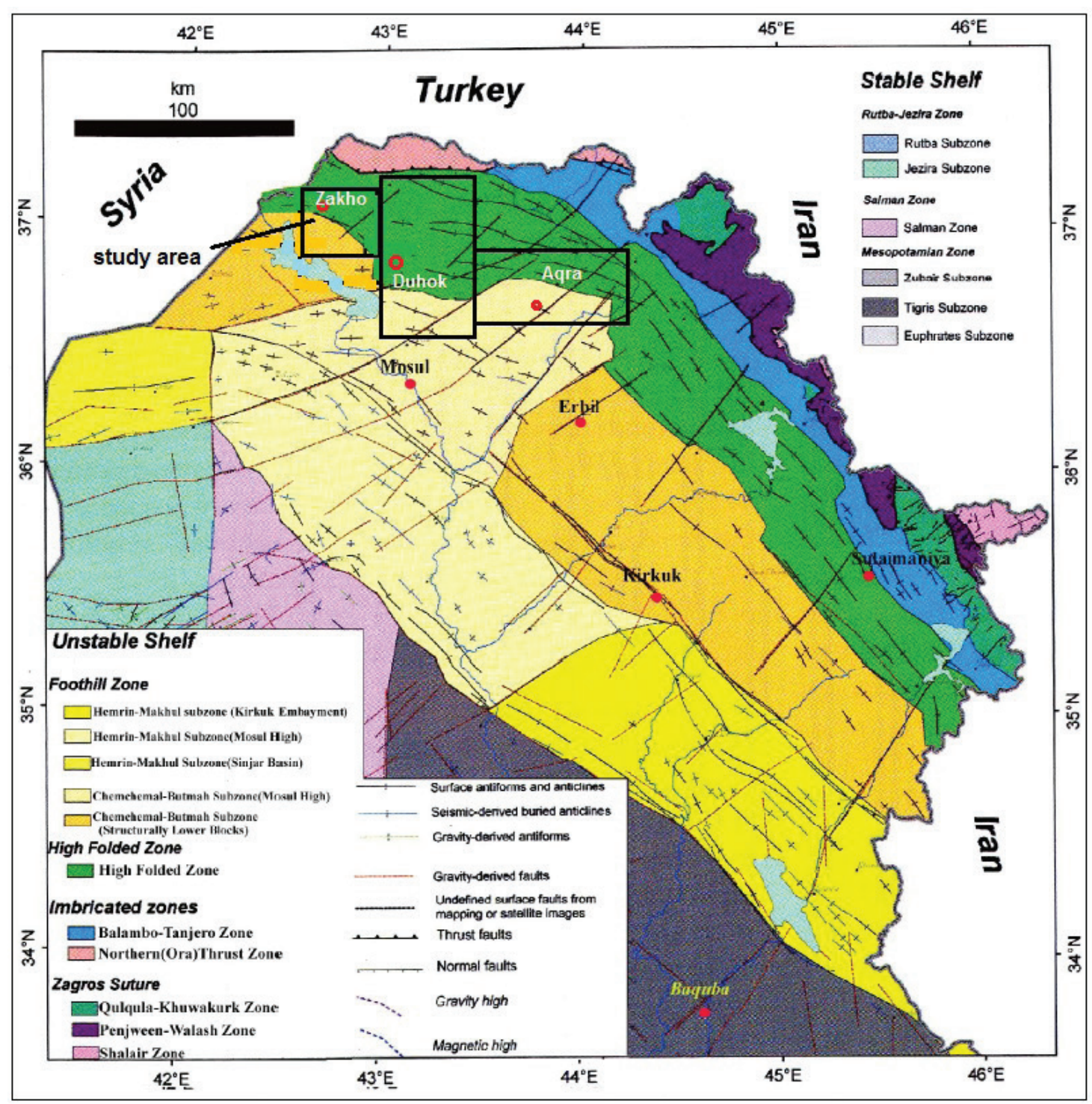

Figure 1. Tectonic zones and structural elements of the unstable shelf (After Jassim and Goff, 2006), with location of study regions.

Iraq was divided into three tectonicallydistinct regions by Jassim and Goff (2006). One is the Stable Shelf with broad buried arches and antiforms without anticlines on the surface; another is the Unstable Shelf, and the third is the Zagros Suture, which contains thrust sheets of radiolarian chert, igneous and metamorphic rocks. These three regions have tectonic subdivisions that appear to be N-E in the Stable Zone and NE-SW or E-W in the Unstable Zone and Zagros Suture. Tectonic movements during Paleozoic are responsible for the N-E trend. The E-W and NE-SW trends are due to the recent Alpine orogenesis of Cretaceous. Zagros Suture was formed in the New Tethys during the abduction and collision phases of Late Cretaceous and Miocene-Pliocene thrust over the Arabian Plate. There are many fold structures in this block (e.g. Dahkan, Kand, Shaikhan, Duhok, Birifka, Bekher, Chia Gara, Maten, Aqra, Piris, Atrush, and Perat anticlines). The folds of this 
block become tighter and higher toward the north and northeast (Figure 1).

There are several common geomorphologic features in the studied area such as agricultural plains with drainage patterns formed dendritically, valleys, foothills, low mountains, and high mountains. These geomorphologic features are cut into by fluvial erosion. The elevation of this area ranges between $250 \mathrm{~m}$ (north of Mosul city) to $1910 \mathrm{~m}$ (northeastern Duhok region close to mountain peaks). Figure 2 shows the location of the study regions on a Digital Elevation Model (DEM) of northern Iraq. across the Demir Dagh and Guwair petroleum anticlines. Ghaib et al. (1998) carried out a local reconnaissance gravity survey that covered about $600 \mathrm{~km}^{2}$ on the Sulaivany plain northeast of Dohuk city. Al-Shaikh and Ahmad (2005) conducted shallow geoelectric investigations of the Mosul Area and discovered new subsurface structures with hydrocarbon probabilities. Since there has been no regional gravity examination of the study area, with the exception of some local studies, the present work fills an important role in complementing the IPC Bouguer map of Iraq and plotting new gravity images.

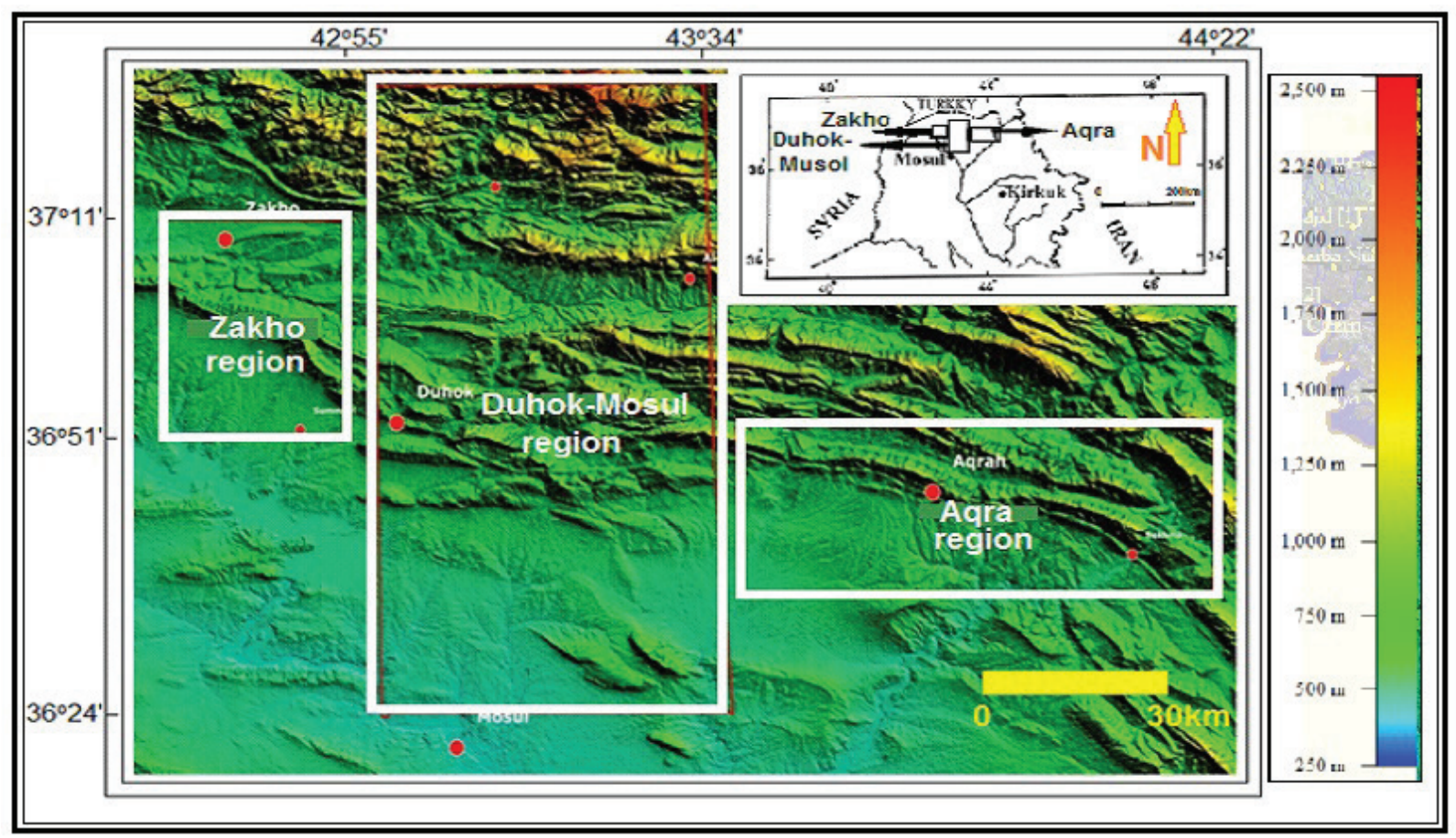

Figure 2. Location of study regions on Digital Elevation Model (DEM) of northern part of Iraq.

Geophysical data are few for the northern and northeastern parts of Iraq although some local surveys were carried out around the Erbil area. The Bouguer anomaly map of Iraq published by Sayab and Valek (1968) did not cover the northern and northeastern parts. Mutib (1980) conducted a gravity investigation on Erbil plain

\section{MATERIALS AND METHODS}

\section{Field Work}

The Earth's gravitational field is a natural global field that attracts every mass with a definite density and weight to the center of the Earth. This field can be measured in the Earth's 
surface, air, sea, a borehole or inside a mine. Different gravity measurements have therefore been established; namely, aerogravity, marine gravity, borehole gravity, and surface gravity. As a result, (i) geodetic research, (ii) crustal study surveys, (iii) oil exploration studies and (iv) mineral mining surveys all use entirely different measurements in terms of surface gravity. For this reason, the distance between two consecutive gravitational stations in a square grid gravity survey may be approximately $100 \mathrm{~km}$ for a geodetic survey or up to ten meters for a mineral survey. The Earth's normal gravity field ranges from 978.0327 gal on the equator to 981.2186 gal at the poles. Point-to-point differences in the gravity field are considered as deviations of gravity $(\Delta \mathrm{g})$ in $\mathrm{mGal}$ units. In gravity research, variations in the Earth's gravitational field caused by differences in subsurface rock density are measured. These variations in the gravity field lead to the interpretation of geological processes in the subsurface. The observed gravity values ( $\mathrm{g}$ ) include the influence of all the Earth's masses and effects due to the rotation of the Earth and its tides (Roy, 2008).

LaCoste and Romberge Gravimeter (model $\mathrm{G})$ was used in this study. It has a range of more than $7000 \mathrm{mGal}$, reading accuracy of $\pm 0.01 \mathrm{mGal}$ and drift of less than $1 \mathrm{mGal} / \mathrm{month}$. When this gravimeter was calibrated before the fieldwork, the calibration factor did not change perceptibly with time. This eliminated the need for frequent checks of the calibration during fieldwork. The instrument did not give us any trouble during the fieldwork period.

The precision of altitude within an acceptable limit is required in gravity surveying for different stations. Achieving the required precision is often the major cost of fieldwork. In this study, all gravity stations were surveyed for relative easting, northing, and elevation using a Garmin (72) Global Positioning System (GPS). The elevation of the station relative to sea level shows an accuracy \pm $4 \mathrm{~m}$ when it is used continuously in the field. The Garmin (72) GPS did not exceed a few meters for the horizontal accuracy of the coordinates.

The primary base station (Pst) is known as absolute gravity and the elevation station was located in Mosul University (Al-Shaikh et al., 1975). The absolute value of this station is $979789.46 \mathrm{mGal}$, which was used as the reference point for other stations in the area under review. The absolute value of gravity could be found for those stations from the absolute value of the (Pst.). In addition, eight secondary base stations (Sst) were established in the studied area and tied with (Pst). Tables $(1,2,3,4)$ show the tying information and Table 5 shows the secondary base stations and the stations tied with them in the study area.

Transportation of the gravimeter from the base station to other stations, and from one station to another, was the most time-consuming aspect. Precautions taken during the work were:

1) Observation points were kept away from artificial or natural activities.

2) Leveling the instrument was carried out carefully.

3) The instrument was kept in the shadow of the observer to prevent direct sunlight.

4) Sudden jerks or mechanical disturbances were avoided. 
Table 1. Tying information between Mosul's primary station (Pst) and five secondary stations (Sst) on 3/6/2010. Pst: Primary station, Sst: Secondary station.

\begin{tabular}{|c|c|c|c|c|c|c|c|c|}
\hline $\begin{array}{c}\text { Station } \\
\text { location }\end{array}$ & Time & $\begin{array}{c}\text { Scale } \\
\text { division } \\
\text { (S.D.) }\end{array}$ & mGal & $\begin{array}{c}\text { Elevation } \\
\text { (m) }\end{array}$ & Latitude & Longitude & $\begin{array}{c}\text { Sst - Pst } \\
\text { (mGal) }\end{array}$ & $\begin{array}{c}\text { Absolute } \\
\text { value }\end{array}$ \\
\hline Pst Mosul & $\begin{array}{l}09: 26 \\
15: 26\end{array}$ & $\begin{array}{l}3388.45 \\
3388.43\end{array}$ & $\begin{array}{l}3597.32 \\
3597.30\end{array}$ & & & & & 979789.46 \\
\hline Sst 5 Filfayl & $\begin{array}{l}10: 02 \\
13: 01\end{array}$ & $\begin{array}{l}3384.85 \\
3384.83\end{array}$ & $\begin{array}{l}3593.50 \\
3593.47\end{array}$ & 315 & $36,32,00.40$ & $43,01,50.30$ & -3.828 & 979785.63 \\
\hline Sst 2 Bahindawa & $\begin{array}{l}10: 31 \\
13: 25\end{array}$ & $\begin{array}{l}3356.64 \\
3356.62\end{array}$ & $\begin{array}{l}3563.54 \\
3563.52\end{array}$ & 422 & $36,44,02.10$ & $43,02,16.30$ & -33.781 & 979755.68 \\
\hline Sst 1 Badriyah & $\begin{array}{l}10: 48 \\
13: 43\end{array}$ & $\begin{array}{l}3351.83 \\
3351.85\end{array}$ & $\begin{array}{l}3558.43 \\
3558.45\end{array}$ & 439 & $36,42,11.00$ & $43,04,24.00$ & -38.871 & 979750.59 \\
\hline Sst 3 Tall kef & $\begin{array}{l}11: 17 \\
14: 09\end{array}$ & $\begin{array}{l}3379.94 \\
3379.91\end{array}$ & $\begin{array}{l}3588.28 \\
3588.25\end{array}$ & 309 & $36,30,42.00$ & $43,07,15.30$ & -9.044 & 979780.42 \\
\hline Sst4 Khursabad & $\begin{array}{l}11: 55 \\
14: 40\end{array}$ & $\begin{array}{l}3374.84 \\
3374.85\end{array}$ & $\begin{array}{l}3582.87 \\
3582.88\end{array}$ & 299 & $36,29,13.10$ & $43,13,26.40$ & -14.433 & 979775.03 \\
\hline
\end{tabular}

Table 2. Tying between Mosul primary station and Bashiqa secondary station on 12/6/2010.

\begin{tabular}{|c|c|c|c|c|c|c|c|c|}
\hline $\begin{array}{c}\text { Station } \\
\text { location }\end{array}$ & Time & $\begin{array}{c}\text { Scale } \\
\text { division } \\
\text { (S.D.) }\end{array}$ & mGal & $\begin{array}{c}\text { Elevation } \\
\text { (m) }\end{array}$ & Latitude & Longitude & $\begin{array}{c}\text { Sst - Pst } \\
\text { (mGal) }\end{array}$ & $\begin{array}{c}\text { Absolute } \\
\text { value }\end{array}$ \\
\hline Pst Mosul & $\begin{array}{l}09: 21 \\
15: 55\end{array}$ & $\begin{array}{l}3388.47 \\
3388.19\end{array}$ & $\begin{array}{l}3597.34 \\
3597.04\end{array}$ & & & & & 979789,46 \\
\hline Sst 6 Bashiqa & $\begin{array}{l}10: 15 \\
15: 26\end{array}$ & $\begin{array}{l}3367.94 \\
3367.99\end{array}$ & $\begin{array}{l}3575.54 \\
3575.59\end{array}$ & 285 & $36,24,47.6$ & $43,16,44.9$ & -21.635 & 979767.83 \\
\hline
\end{tabular}

Table 3. Tying between Mosul primary station and Bekhma secondary station on 20/7/2010.

\begin{tabular}{|c|c|c|c|c|c|c|c|c|}
\hline $\begin{array}{l}\text { Station } \\
\text { location }\end{array}$ & Time & $\begin{array}{c}\text { Scale } \\
\text { division } \\
\text { (S.D.) }\end{array}$ & mGal & $\begin{array}{c}\text { Elevation } \\
\text { (m) }\end{array}$ & Latitude & Longitude & $\begin{array}{c}\text { Sst - Pst } \\
\text { (mGal) }\end{array}$ & $\begin{array}{c}\text { Absolute } \\
\text { value }\end{array}$ \\
\hline Pst Mosul & $\begin{array}{l}07: 13 \\
18: 07\end{array}$ & $\begin{array}{l}3388.34 \\
3388.08\end{array}$ & $\begin{array}{l}3597.20 \\
3596.93\end{array}$ & & & & & 979789.46 \\
\hline Sst 7 Bekhma & $\begin{array}{l}10: 06 \\
15: 47\end{array}$ & $\begin{array}{l}3267.48 \\
3268.12\end{array}$ & $\begin{array}{l}3468.86 \\
3469.54\end{array}$ & 621 & $36,41,3.2$ & $44,17,44.8$ & -127.865 & 979661.60 \\
\hline
\end{tabular}

Table 4. Tying between Mosul primary station and Besary secondary station on 18/10/2010.

\begin{tabular}{|c|c|c|c|c|c|c|c|c|}
\hline $\begin{array}{l}\text { Station } \\
\text { location }\end{array}$ & Time & $\begin{array}{c}\text { Scale } \\
\text { division } \\
\text { (S.D.) }\end{array}$ & mGal & $\begin{array}{l}\text { Elevation } \\
\text { (m) }\end{array}$ & Latitude & Longitude & $\begin{array}{c}\text { Sst - Pst } \\
(\mathrm{mGal})\end{array}$ & $\begin{array}{c}\text { Absolute } \\
\text { value }\end{array}$ \\
\hline Pst Mosul & $\begin{array}{l}07: 43 \\
19: 55\end{array}$ & $\begin{array}{l}3387.14 \\
3387.71\end{array}$ & $\begin{array}{l}3595.93 \\
3596.53\end{array}$ & & & & & 979789.46 \\
\hline $\begin{array}{l}\text { Sst } 8 \\
\text { Besary }\end{array}$ & $\begin{array}{l}10: 15 \\
18: 02\end{array}$ & $\begin{array}{l}3313.08 \\
3313.40\end{array}$ & $\begin{array}{l}3517.28 \\
3517.62\end{array}$ & 660 & $36,51,12.4$ & $43,03,35.0$ & -74.185 & 979715.28 \\
\hline
\end{tabular}


Table 5. Secondary base stations and stations tied to them in the study area.

\begin{tabular}{cc}
\hline S.B.S & Stations \\
\hline S.B.S.1 Badriyah & $(1-10)$ \\
S.B.S.2 & $(11-20)$ \\
Bahindawa & $(21-62),(155-172)$ \\
S.B.S.3 Tall kef & $-774)$ \\
S.B.S.4 & $(63-114),(173-209),(420-456),(715$ \\
Khursabad & $(210-371)$ \\
S.B.S.5 Filfayl & $(115-154),(457-714),(819-868)$ \\
S.B.S.6 Bashiqa & $(775-818)$ \\
S.B.S. 7 Bekhma & \\
S.B.S.8 Besary &
\end{tabular}

The fundamental step in obtaining the potential measurements is fieldwork. As a result, the aims of this fieldwork determined the form of survey lines and parameters of the station locations. The manner of the fieldwork consists of the station's array; and the method used is commonly either traverse, grid or random. In this study, the random method was used for arraying the stations due to major obstacles (mountains and valleys) in the study area. To facilitate the survey, 868 gravity stations near and along highways, roads, and their branches were established depending upon feasibility of access and the spacing pattern necessary to detail the features (Figure 3).

The gravity base station was adapted to correct the gravity readings for the effect of drift in every station (Dobrin, 1988) (Figure 4).

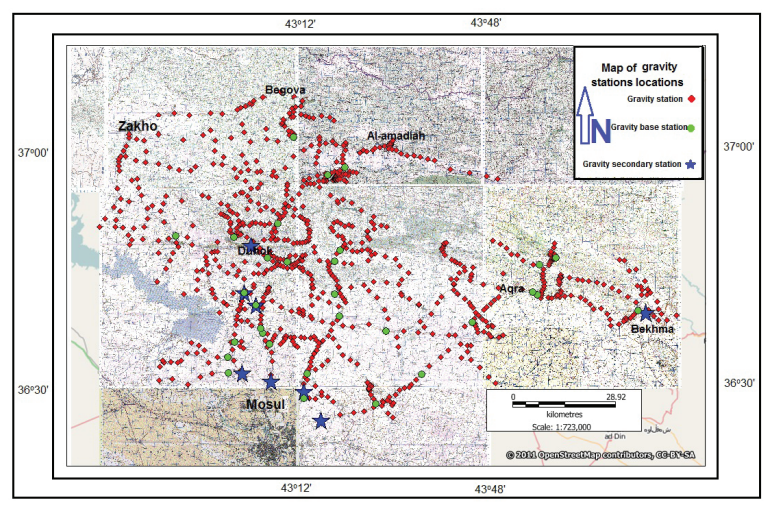

Figure 3. Map of study area showing location of gravity stations.

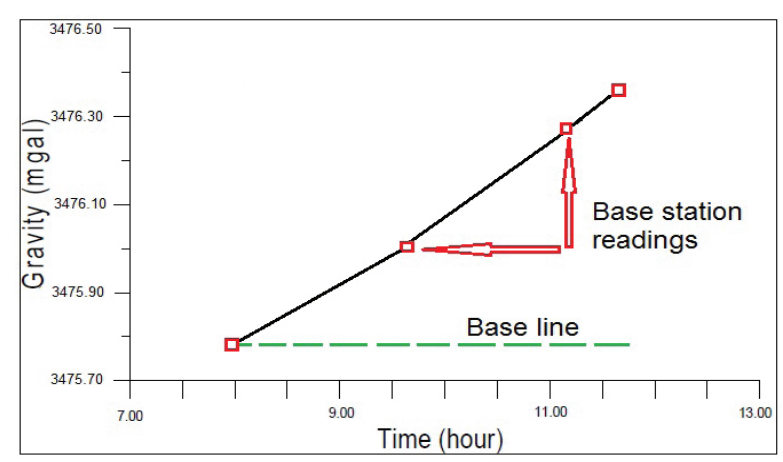

Figure 4. Drift curve for one-day gravity work $7 / 08 / 2010$.

The location of the stations by longitude, latitude, and elevation are important parameters that should be known to correct the field measurements. Additionally, the spacing between stations is related directly to the type of feature which is to be studied; it determines the length of the profiles and affects the stations' location. The spacing between our stations ranged between 500 $\mathrm{m}$ and $5000 \mathrm{~m}$ - $^{-}$

The observed gravity measurements obtained in the field usually include various effects which must be removed to leave the effect of the subdatum density irregularities only. The Bouguer anomaly of the gravity at a point is the difference between the observed value $\left(\mathrm{g}_{\text {obs }}\right)$ adjusted by the algebraic sum of all the necessary corrections $\left(\sum_{\text {corr }}\right)$ and that at the base station $\left(g_{\text {base }}\right)$ :

$\Delta g_{B}=\mathrm{g}_{\text {obs }+} \sum_{\text {corr }} \cdot g_{\text {base }}$

$\mathrm{g}_{\text {obs }}=\left(\mathrm{g}_{\text {abs. }}-g_{\text {theo. }}\right)$

where $g_{a b s .}$ is the absolute gravity value at the measurement point. This implies a known absolute value at the base station and $g_{\text {theo }}$ is the theoretical gravity value at the geographic station latitude $(\phi)$ at sea level.

The theoretical gravity value, which is usually denoted by $\left(g_{\phi}\right)$, varies over the surface of the Earth because of its ellipsoidal shape. The International Union of Geodesy and Geophysics 
(IUGG) in 1930 proposed a formula to calculate $\mathrm{g}_{\phi}$ at any latitude:

$\mathrm{g}_{\phi}=9.78049\left(1+0.0052884 \sin ^{2} \phi-0.0000059 \sin ^{2} 2 \phi\right) \mathrm{m} / \mathrm{s}^{2}$

It is important to mention here that the IPC's Bouguer map had applied the above formula (Mutib, 1980), which was applied in the present study for tying and comparison.

For the purpose of Bouguer correction, the value of $2.175 \mathrm{~g} / \mathrm{cm}^{3}$ was used by the IPC for gravity reduction in the Iraqi territories (Sayyab and Valek, 1968; Abbas and Masin, 1975). Therefore, this value was used in the present study. Sea level was taken as the datum plane.

The data obtained after reduction of the raw data may be affected by several errors; the first is produced by the instrument itself and the second by field and reduction procedures. Instrumental errors arise from an inaccurate reading of the data. Repeated readings in 61 stations showed an error in the observation of $( \pm 0.04) \mathrm{mGal}$ in $\left(\mathrm{g}_{\text {obs }}\right)$. The second type of error affects the gravity anomaly values more seriously. These often stem from:

1) Density: An error in density measurement of $0.01 \mathrm{~g} / \mathrm{cm}^{3}$ gives rise to a Bouguer error of $0.04 \mathrm{mGal}$ per $100 \mathrm{~m}$. Hence for a maximum elevation error of one meter, the density error is negligible, i.e. $\pm 0.014 \mathrm{~g} / \mathrm{cm}^{3}$

2) Free-air elevation: An error of $0.3086 \mathrm{mGal}$ will result from each meter error in elevation when free-air correction is made. Thus, this type of error is the most serious and the elevation of the stations must always be measured as precisely as possible. In our study area, the elevation error was about $4 \mathrm{~m}$.

3) Bouguer elevation: An error of $(0.04193 \rho)$ $m$ Gal will result from each meter error in elevation when Bouguer correction is done.

4) Location: This error comes from the degree of accuracy in locating the position of each station. In the study area, this error does not exceed $25 \mathrm{~m}$ (about 1 second in latitude). The valuable notes about sources and magnitude errors given by Lynch and King (1983) were considered in the course of this study.

5) Terrain elevation: An error may occur from the degree of accuracy in the elevation of each station and the density used in this correction (2.175).

The errors encountered in this study are listed in Table 6.

The total error in the Bouguer anomaly can be calculated using this formula:

$E_{\text {total }}=\sqrt{E_{g}^{2}+E_{F_{a}}^{2}+E^{2} B+E^{2} l_{\text {a }}+E^{2}{ }_{F}}= \pm 1.297 \mathrm{mGal}$

Table 6. Source and magnitudinal effects of errors.

\begin{tabular}{lc}
\hline \multicolumn{1}{c}{ Source } & $\begin{array}{c}\text { Magnitudinal Effect } \\
(\mathbf{m G a l})\end{array}$ \\
\hline Measurement error $\left(g_{o}\right)$ & 0.04 \\
Elevation (Free-air) error $\left(F_{a}\right)$ & 1.23 \\
$\begin{array}{l}\text { Elevation (Bouguer) error }\left(B_{c}\right) \\
\text { including density }\end{array}$ & 0.38 \\
Latitude error $(l a t)$ & 0.02 \\
Terrain elevation error $(T c)+$ & $0.0006+0.15$ \\
Density error & \\
\hline
\end{tabular}

\section{RESULTS}

\section{Terrain correction grid image}

In an area of irregular topography, the gravity effect of undulations above and below the gravity level of measurements is called terrain correction. Terrain correction is required if the gravity influence due to the topography between any station and the base station is above the gravimeter's accuracy. Hammer's method, which many geophysicists still use, is the most commonly used method for terrain correction. The Hammer process is easily understandable but is difficult to automate in a computer program. Consequently, terrain correction is generally done by hand when using the Hammer approach. Nevertheless, it is a labor-intensive task to manually calculate 
these corrections using topographical maps. The Hammer method, according to Leaman (1998), is manual, repetitive and prone to errors in estimation.

A detailed Digital Elevation Model (DEM) and the computational power that is currently available are necessary and efficient for performing these corrections (Hinz et al., 2005; Nabighian et al., 2005 and Chen, 2009). A DEM image is a topographical digital map, and every point represents a fixed zone size (normally square) on an $\mathrm{XY}$ plane, with $\mathrm{Z}$ being the height relative to sea level. The dimension of the square region is referred to as the DEM image resolution. In our study area, the resolution of DEM images is $30 \mathrm{~m}$. Each elevation point within the DEM image compared to the altitude of the gravitational station (called relative height) is measured. The vertical part of the gravitational attraction between the gravitational station and the prism is defined by a rectangular prism with a uniform density (2.175). For every neighboring pixel, this procedure is repeated on the pixel station within a given distance $(167 \mathrm{~km}$ from the position of a gravitational station around 1.5 in latitude or longitude). The vertical attractions of every pixel near to the data are calculated and summed to find the total terrain correction.

A full system of processing and reduction of gravity data is available from the Geosoft Oasis Montaj (GOM, 2008) and Terrain Correction Software (TCS) extensions. The extension measures the regional terrain correction from a rough regional Digital Elevation Model (DEM), based on a finer DEM model, covering the field of study. The process generates a "regional correction grid" which represents terrain corrections over a local correction distance. This result is repeated for detailed corrections in each position of gravity observed. A terrain correction grid of 30 meters (DEM) was calculated. The method used with DEM and incorporated in the Oasis Montaj system for the application of automatic terrain corrections is outlined below. The approach divides the area around the gravity station into $\mathrm{x}-\mathrm{y}$-plane cells. Interpolation in the DEM grid, which is gridded at available gravity heights, assigns a mean elevation for each cell to increase precision. Prisms are created by projecting the cells down or up the station's elevation level. A standard density $\left(2.175 \mathrm{~g} / \mathrm{cm}^{3}\right)$ is assigned to each prism and the terrain correction at the station is then measured as the sum of the impacts caused by each prism. The cell area increases according to the distance from the station to reduce measurement time. Cell area is influenced when focused circles based on the station are considered. In the closest circle to the station, each cell has a user-defined area that allows the user to employ any high-resolution DEM. In each subsequent circle, the area of the cells is doubled.

In our analysis, a regional terrain correction grid (261-278 km) was created using a regional DEM grid of $45 \mathrm{~m}$ as topographical data. As per the software manual, a more highly-sampled local DEM grid (179-175 km) was created, of $5 \mathrm{~m}$, as the station elevation data (Figure 5).

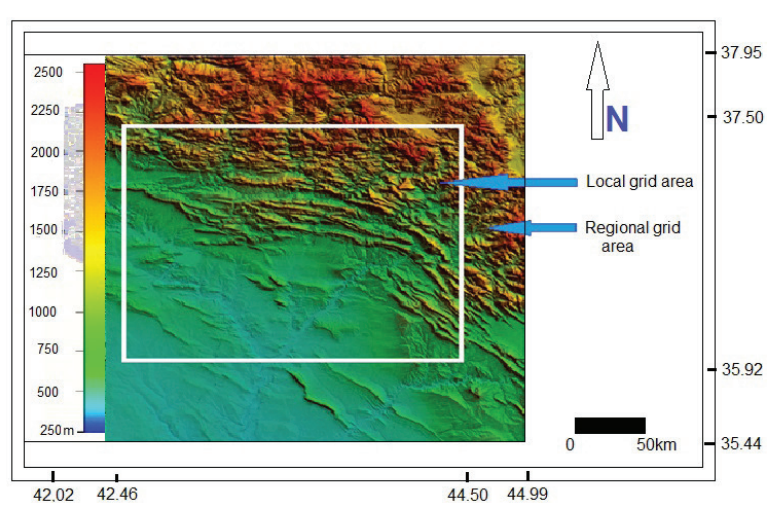

Figure 5. Regional and local grid areas generated for terrain correction calculation.

The terrain correction map was then drawn for the study area (Figure 6). Total values ranged from 0.00 to $82.28 \mathrm{mGal}$, averaging 33.03. It was noted that the presence of minimal values in regions 
reflecting lower differences in elevation variance usually occurred in mountainous areas. By contrast, a foothill zone (excepting its mountain) indicated high values, which may be attributed to the effects of faraway regional elevations. These values were added to those of the Bouguer Anomaly.

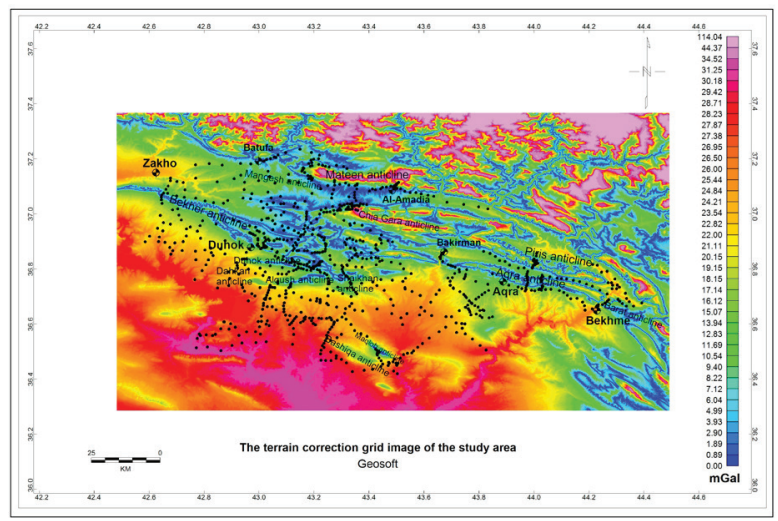

Figure 6. Terrain correction grid image of study area.

\section{Bouguer anomaly map}

The Bouguer anomaly map of the study area was determined using the same parameters previously used by the IPC for comparing and linking information between the current study and the adjacent IPC map (Figure 7). The present gravity map shows a good correlation with the old results, with a gradual decrease in the regional trend to the northeast. Such a decrease has already been explained by the negative density contrast between the light sedimentary cover and the denser underlying basement complex, which deepens gradually to the northeast.

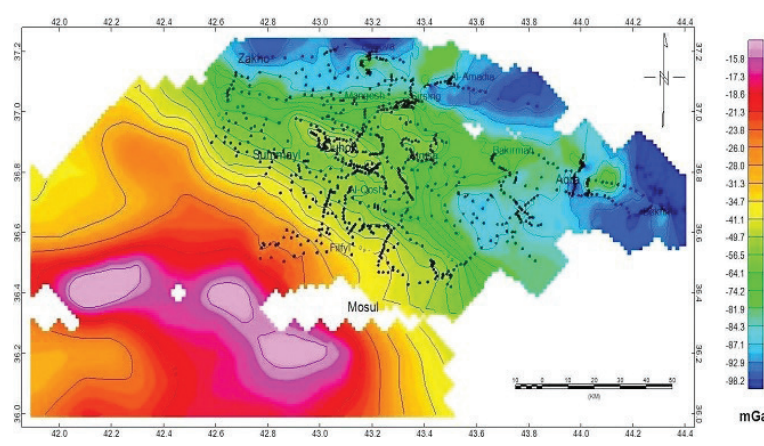

Figure 7. Tying of Bouguer anomaly map of study area with IPC Bouguer anomaly map.

For the purpose of clarifying the difference between the map generated conventionally and the complete Bouguer anomaly map of the study area, a comparison between conventional methods and the present study in computing gravity anomalies was performed and is included in Table 7.

Table 7. Comparison between applied parameters of IPC and the present study.

\begin{tabular}{|c|c|c|}
\hline Components & $\begin{array}{l}\text { Conventional use in } \\
\text { IPC Bouguer map }\end{array}$ & Used in this study \\
\hline Absolute gravity value & $\begin{array}{l}\text { Ain Zala's base } \\
\text { station }\end{array}$ & Mosul's base station (Al-Shaikh et al.,1975) \\
\hline Datum Plane & Mean Sea Level & Mean Sea Level \\
\hline Reduction density & $2.175 \mathrm{~g} / \mathrm{cm}^{3}$ & $2.175 \mathrm{~g} / \mathrm{cm}^{3}$ \\
\hline Theoretical gravity & $\begin{array}{l}\text { Referenced to } \\
\text { (IUGG) }\end{array}$ & Referenced to (IAG) formula in 1971 \\
\hline Terrain correction & N/A & Applied by using Oasis Montaj program of 2008 \\
\hline Atmospheric correction & N/A & Analytical estimate of atmospheric mass gravity effect (Hinze, 2005) \\
\hline Isostatic correction & N/A & $\begin{array}{l}\text { Applied with density contrast at crust-mantle boundary about } 0.33 \mathrm{~g} / \mathrm{cm}^{3} \text { and crust } \\
\text { thickness about } 35 \mathrm{~km} \text { from sea level by Oasis Montaj Program } 2008\end{array}$ \\
\hline
\end{tabular}


Figure 8 illustrates the Bouguer anomaly map of the study area produced using new techniques.
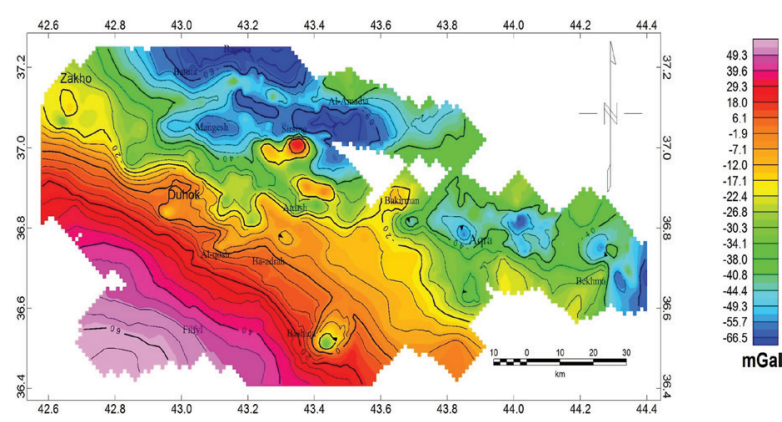

Figure 8. Bouguer anomaly map of study area.

The greatest difference between the two maps is attributed to terrain gravity effects and new theoretical gravity formulae (IAG, 1971). The terrain correction values added to the Bouguer anomaly values led to an increase in the values of the Bouguer anomaly map in the present study.

The 1930s formula (used in IPC surveys) differs by about $12.5 \mathrm{mGal}$ from the 1971 formula. In addition, an atmospheric formula according to the present study added about $0.8 \mathrm{mGal}$ to the Bouguer anomaly values. The contour values of the recent Bouguer anomaly map range between +65 and $-75 \mathrm{mGal}$. In the northern and northeastern parts of the study region, the map shows three "low" gravity anomalies, with E-W trends. The first negative anomaly is eastward from Zakho near Bagova and Batufa villages. The second gravity low is between Mangesh and Al-Amadia villages. The third negative anomaly is divided into three small anomalies between Aqra and Bekhma villages. All of these negative anomalies are an extension of the largest plain in the area studied, which may indicate the presence of thick sediments. There are four small closed negative anomalies extending parallel to the previous anomalies; the first is south of Zakho city (south of Gulley Zakho) with a contour value of about -10 mGal, the second is south of Duhok city (nearest to Duhok mountain) with a contour value of about
$-5 \mathrm{mGal}$, the third is near to Alqush village with a contour value of about $-5 \mathrm{mGal}$, and the last is east of Mosul city (near to Bashiqa village) with a contour value of about $-12 \mathrm{mGal}$.

There are four positive closed anomalies in the study area with E-W trends. The first is in the south of Zakho with a value of about $5 \mathrm{mGal}$, the second gravity "high" is near to Sirsing village over Gara mountain with a value of about $40 \mathrm{mGal}$, the third is north of Atrush village with a value of about 20 $\mathrm{mGal}$, and the last is near to Bakirman village with a contour of about $7 \mathrm{mGal}$. Visual inspection of the recent Bouguer anomaly map displays a relatively rapid decrease from the south toward the north and northeast with a maximum difference of 140 $m G a l$ that may indicate an increase of sedimentary cover thickness in the direction of those trends.

\section{Free-air anomaly map}

Mean free-air gravity anomalies (FAA) are often needed in geodesy for gravity field modeling (Janák and Vanícek, 2005). FAA mimic signs of density variations in the Earth's crust and upper mantle (Dobrin and Savit, 1988) as well as topographic changes. FAA is highly correlated with the height of observation points. This means that the "roughness" of the free-air anomalies is similar to that of the topography (Amos, 2007).

The FAA map of the study area in Figure 9 shows the difference between observed (without correcting for Bouguer and terrain effects) and theoretical gravity values. If, as is usually done, a normal free-air gradient of $=0.3086 \mathrm{mGal} / \mathrm{m}$ is used for the free-air reduction; then the FAA refers, strictly speaking, to the Earth's physical surface (to ground level) rather than to the geoid (to sea level), as mentioned by Li and Götze (2001). The Bouguer effect is strongly negative and the FAA is low in the middle of a large area that may be compensated isostatically. The BA and FAA anomalies are equal to zero away from mountainous regions. On mountains, the mountains' block mass 
raises the gravity determined in contrast with the reference value and results in a positive free-air anomaly (Lowrie, 2007). Consequently, the FAA over the middle parts of the study area is positive, averaging about $+50 \mathrm{mGal}$, while over the Chia Gara and the Matean mountains and surrounding area, stronger anomalies up to $+100 \mathrm{mGal}$ can be seen. On the contrary, the Bouguer's anomaly is very negative, but the FAA is small in different regions of the research area, which is isostatically compensated.
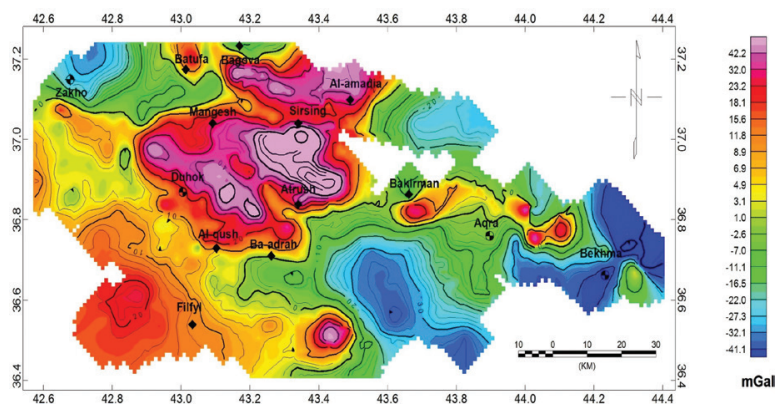

Figure 9. Free-air anomaly map of study area.

\section{Crust thickness map}

Improved knowledge of crustal thickness variations can yield important constraints on the local stress field in combination with regional plate tectonic stress fields to provide new insight into earthquake hazards. In addition, these results may contribute to exploration of the region's mineral and energy resources to promote economic development (Hernandez, 2006). GOM is able to obtain the discontinuity Moho depth by knowing the difference in density between crust and mantle, and also the Moho depth for a study area with complete Bouguer anomalies and inversion process (Asgari and Mehramuz, 2015). The mean crustal thickness in the study area is 35 $\mathrm{km}$ (Hafidh et al., 2007) with a varying crustal root into the mantle. The densities used were $2.67 \mathrm{~g} /$ $\mathrm{cm}^{3}$ for the continental crust and $0.33 \mathrm{~g} / \mathrm{cm}^{3}$ as a contrast across the Moho boundary.
The present study applied a correction to the varying depth of a hypothetical crust-mantle boundary caused by differential topographic or bathymetric loads above or below the ellipsoid. Finally, Moho discontinuity depths for the study area were calculated using GOM for acquisition of the crustal thickness map from the topographical and Bouguer anomaly grids (Figure 10).
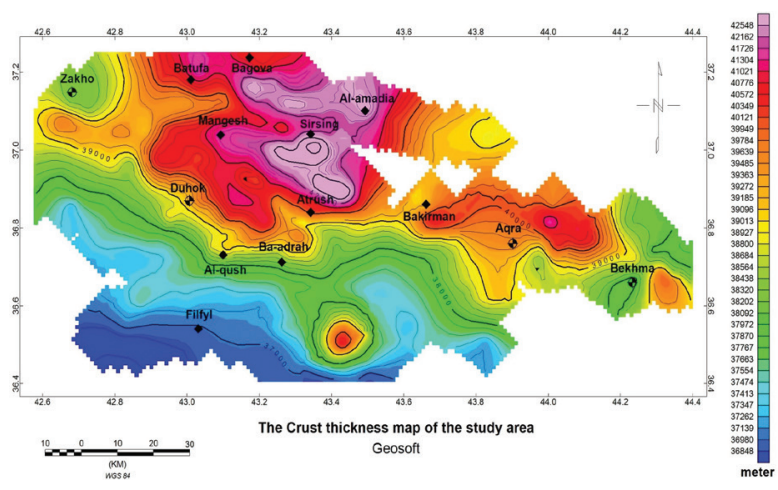

Figure 10. Crust thickness map determined from topographical and Bouguer anomaly grids of study region.

\section{Isostatic residual anomaly map}

Isostatic correction removes a regional gravity gradient based on the physics of isostasy. It is assumed that the topography in the study area is isostatically balanced, and therefore there is a deficient density of the mass below mountainous areas relative to valleys. The isostatic corrections of the collected gravity data were calculated using GOM.

Assumptions in making the isostatic calculation include: 1) a crustal thickness of 35 $\mathrm{km}$ at sea level (Hafidh et al., 2007); 2) a density contrast of $0.33 \mathrm{~g} / \mathrm{cm}^{3}$ across the Moho boundary; and 3) a crustal density of $2.67 \mathrm{~g} / \mathrm{cm}^{3}$.

Isostatic effects of the gravity data collected in the study area, ranging from $(-35$ to -44$)$ mGal, are shown in Figure 11, which has small values since the range of elevation is minimal. The isostatic residual anomaly was determined 
by eliminating the long gravity effects of wavelengths induced by isostatic compensation, i.e. variations in the crust / upper mantle boundary. The anomaly of isostatic gravity $\left(\Delta \mathrm{g}_{\mathrm{I}}\right)$ is defined as the difference between the anomaly of Bouguer gravity $\left(\Delta \mathrm{g}_{\mathrm{B}}\right)$ and the measured root-zone anomaly $\left(\Delta \mathrm{g}_{\mathrm{R}}\right)$ (Figure 12).

$$
\Delta \mathrm{g}_{\mathrm{I}}=\Delta \mathrm{g}_{\mathrm{B}}-\Delta \mathrm{g}_{\mathrm{R}}
$$
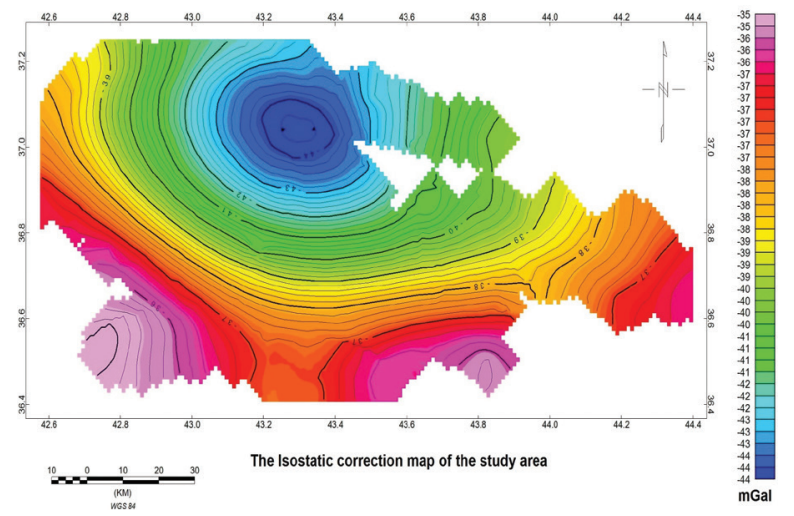

Figure 11. Isostatic correction map of study area.

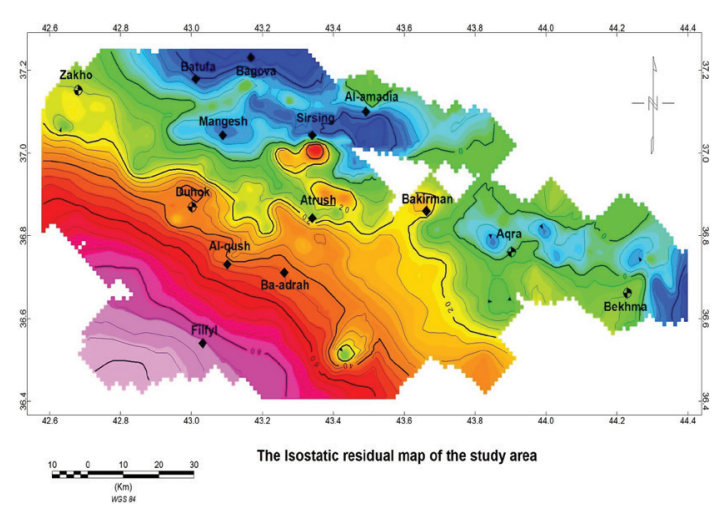

Figure 12. Isostatic residual map of study area.

The topography with its root area is in hydrostatical balance if the isostatic compensation is complete. Both $\Delta \mathrm{gR}$ and $\Delta \mathrm{gB}$ are negative but equal, and the isostatic anomaly, therefore, is zero everywhere $(\Delta \mathrm{gI}=0)$. When over-compensation is involved in eroded topography, a root zone less than the real root zone is proposed. The Bouguer anomaly is due to the larger true source, so the total number of $\Delta \mathrm{gB}$ is greater than that of $\Delta \mathrm{gR}$. A negative isostatic anomaly $(\Delta \mathrm{gI}<0)$ is left by removing the less negative anomaly of the computed root zone. In addition, the topography indicates that the root zone is greater than the real root zone with under-compensation. The Bouguer anomaly is the result of the smaller real root, which means that the total of $\Delta \mathrm{gB}$ is numerically smaller than $\Delta \mathrm{gR}$. Subtracting the major negative rootzone anomaly leaves a positive isostatic anomaly $(\Delta \mathrm{gI}>0)$ (Lowrie, 2007). A dominant NW-SE trend characterizes the Isostatic Residual Map of the study area. This corresponds to changes in the tectonic zones. On the assumption that the isostatic correction has adequately accounted for deep crustal gravity effects, the gravity seen on the isostatic anomaly might indicate a deeper basement. This was evident in the residual isostatic.

The pattern of isostatic anomalies in the study area reflects different structures beneath the mountains. The dominant E-W trend of isostatic gravity contour lines is roughly similar to that of the mountain chain. In the north, the Chia Gara and Mateen anticlines are over-compensated and reach the Aqra area with negative isostatic anomalies of about $-20 \mathrm{mGal}$, while in southern areas there is under-compensation with positive isostatic anomalies of $80 \mathrm{mGal}$. A zero compensation line in the study area was revealed around Chia Gara, Mateen, Mangesh, Aqra, Piris, and Perat. The direction of the compensation line agrees with the Zagros (NW-SE) trend on the isostatic anomaly map.

\section{Regional structures (upper mantle) anomaly}

To investigate the direction of the lithosphere regional structures we chose to use the upward continuation technique as a method for regional/ residual separation. Without modeling and subtracting the response from near-surface structures, a definition of the continued upward 
gravity anomaly will be somewhat uncertain. Long-wavelength anomalies may be caused by large or closely distant small bodies (Lyngsie et al., 2006).

Upper mantle anomalies in the area of research were observed by increasing the residual isostatic anomaly field to $45 \mathrm{~km}$ and then removing it from the previous isostatic residual anomaly (up to $35 \mathrm{~km}$ ). Figure 13 shows the contribution of the Moho interface under the study area.

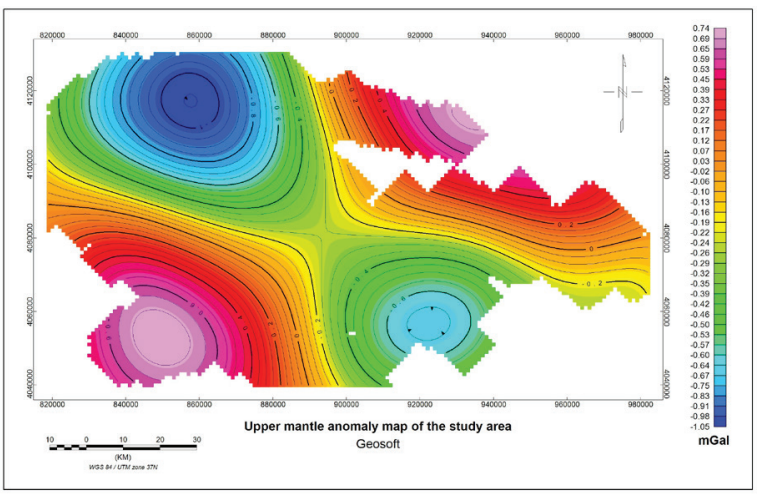

Figure 13. Upper mantle anomaly map of study area.

\section{Upward continuation filters}

This filter is considered to be clean because it produces nearly no side-effects that require other filters or processes to be corrected. This means that the effects of shallow sources and grid noise are often reduced or decreased. In addition, numerically and with modeling programs, upward continuous data can be interpreted. This does not apply to many other filtering processes.

The empirical method of Zeng et al. (2007) can determine the optimal upward continuing height. The method is used to calculate the correlation factor (r) between two successive upward continuous fields. The correlation factor can be determined by increasing the continuous height. The maximum deflection height is the optimal height (Figure 14). This technique was used to isolate the residual anomaly map of the study area.

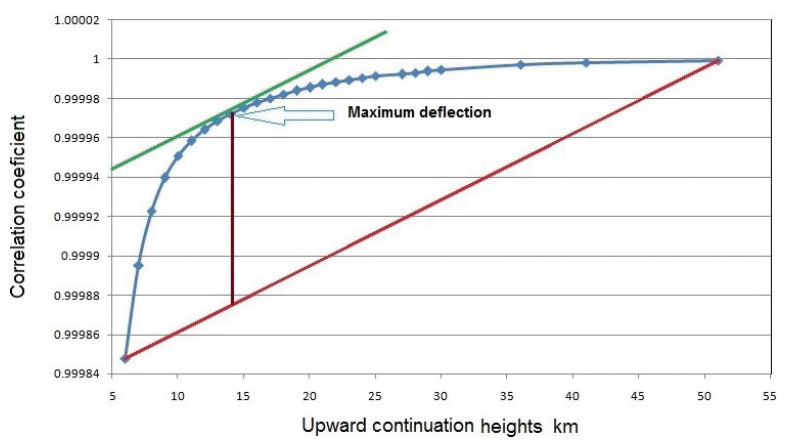

Figure 14. Cross-correlation between continuations of two successive upward heights versus upward heights.

The best level of upward continuation produced was $14 \mathrm{~km}$, which was used to obtain the study area's residual and regional anomaly maps (Figures 15 and 16).
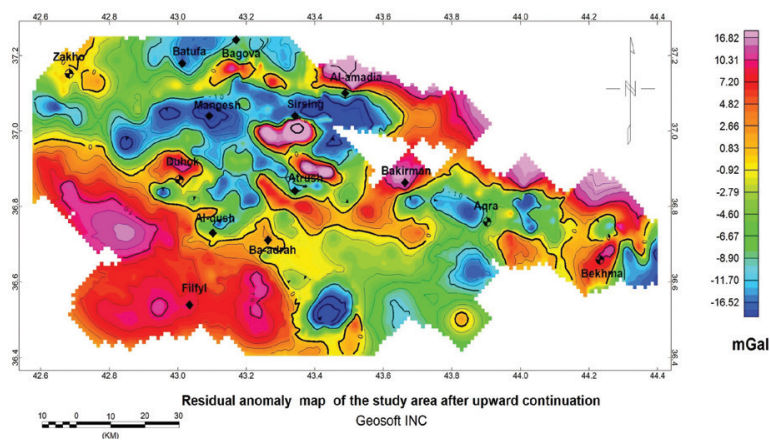

Figure 15. Residual anomaly map of area regarding upward continuation.

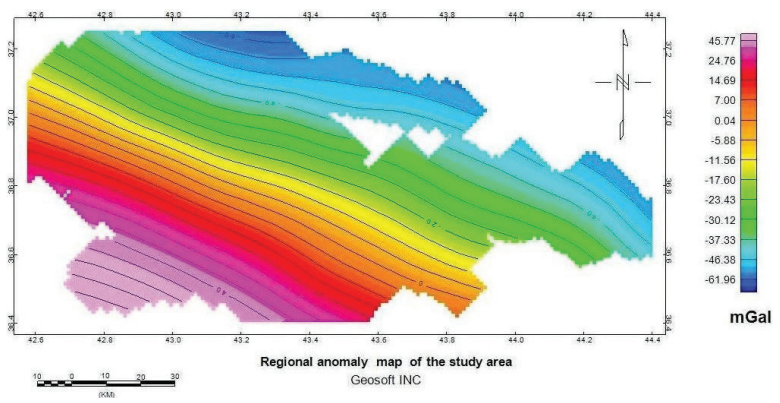

Figure 16. Regional anomaly map of study area after upward continuation. 
The residual map that resulted using the optimum upward continuation method, as seen in Figure 15, shows many positive and negative closed or semi-closed anomalies. These anomalies are described according to regions as follows:

The western part (Zakho region) is characterized by positive or negative anomalies mainly trending E-W and NW-SE. The most important among them is the Bekher negative anomaly, which trends almost E-W, reaching a maximum gravity value of $-16 \mathrm{mGal}$.

The central part (Duhok-Mosul region) is characterized by the presence of many positive and negative closed anomalies trending mostly in $\mathrm{E}-\mathrm{W}, \mathrm{NW}-\mathrm{SE}$, and $\mathrm{N}-\mathrm{S}$ directions. There are five important positive anomalies in this region. The first is Bekher positive anomaly near Duhok city which trends almost NW-SE, reaching a maximum gravity value of $+11 \mathrm{mGal}$, second is Shaikhan positive anomaly near Shaikhan village (over Shaikhan anticline) which trends almost E-W, reaching a maximum gravity value of +8 $\mathrm{mGal}$, third is Atrush positive anomaly (over Atrush anticline) close to Atrush village which trends almost $\mathrm{E}-\mathrm{W}$, reaching a maximum gravity value of $+16 \mathrm{mGal}$, fourth is Chia Gara positive anomaly (over Chia Gara anticline) near Sirsing village, which trends almost $\mathrm{E}-\mathrm{W}$ reaching a maximum gravity value of $+22 \mathrm{mGal}$, and last is the Mateen positive anomaly (over Mateen anticline) near Al-Amadia village which trends almost E-W and reaches a maximum gravity value of $+22 \mathrm{mGal}$.

In addition, there are two negative anomalies in this region. The first is the largest one, extending from south of Zakho to Al-Amadia village, which trends almost $\mathrm{E}-\mathrm{W}$ reaching a maximum gravity value of $-22 \mathrm{mGal}$. The second is near Bashiqa village (over Maqlob anticline) which trends almostNW-SE, reaching a maximum gravity value of $-32 \mathrm{mGal}$. On the other hand, the eastern part (Aqra region) is occupied by three negative and two positive anomalies. The negative anomalies exist around Aqra village (over Aqra anticline) with gravity values of $-15 \mathrm{mGal}$. Regarding the two positive anomalies, the first is near Bakirman village (over the plunge of Aqra anticline) with a gravity value $+16 \mathrm{mGal}$, and the second is close to Bekhma village (over Piris and Perat anticlines) with a gravity value of about $+12 \mathrm{mGal}$. Figure 16 displays the decreasing regional anomaly map toward N-NE.

\section{CONCLUSIONS}

For correlation of data between the current study and the adjacent IPC Bouguer map produced previously, a gravity anomaly map for the study area was drawn up using the same parameters applied by IPC, and then the two maps were tied. The gravity map of the present study is a very good match with the old results, and the regional gravity field trend is characterized by a steady, uniform decrease toward the northeast.

By utilizing up-to-date software and DEM techniques, the new Digital Terrain Modeling (DTM) was applied to provide the final Bouguer anomaly values. Study of the terrain effect in high mountainous areas revealed values ranging between 0 and $82.28 \mathrm{mGal}$. It is noticeable that the presence of minimal values in regions generally reflects a lower difference in elevation variance, which occurs in a mountainous area. By contrast, the foothill zone (excepting its mountains) indicates maximal values, which may be attributed to the impact of faraway regional heights.

The free-air gravity anomaly (FAA) over the middle part of the study area is positive, while stronger anomalies are seen over the Chia Gara and Matean mountains and surrounding areas. Several modern methods were applied to determine the best separation of regional and residual anomalies; it was found that the most realized method was the new empirical upward continuation technique. 
The isostatic residual gravity map of the study area was obtained after removal of the isostatic correction ( -35 to $-44 \mathrm{mGal})$, and thus the depth of Moho discontinuity for the study area was mapped from the topographical and Bouguer anomaly grids to acquire the crustal thickness map. The optimum upward continuation heights were applied to the gravity profiles with values of 4 to $9 \mathrm{~km}$ under sea level, reflecting the basement depth corresponding to the 2D models.

The present research arrived at a new regional geophysical simulation and geological appraisal of the studied area. Thus, it is recommended utilizing recent developments of the Bouguer anomaly concepts based on DEM, TC and GOM techniques to reconstruct previous gravity data.

\section{ORCID}

Marwan Mutib (D) https://orcid.org/0000-0002-2872-6669

Maan Hasan Abdullah Almajid (D) https://orcid.org/0000-0002-3951-4880 Fadhil A. Ghaib (D) https://orcid.org/0000-0002-6762-7196

\section{REFERENCES}

Abbas, M.J., Masin, J., 1975. New geophysical aspects of the basement structure in western Iraq. J. Geol. Soc. Iraq, Special Issue: 1-13.

Al-Shaikh, Z.D., Saleh, S.A., Abdo, H.F.,1975. Contribution to the geology of Shaqlawa - Harir area, Iraqi J. Geo. Soc., Special issue, 55-67.

Al-Shaikh, Z.D., Ahmad, M.M., 2005. New Contribution to the Geology of Mosul Area from Geoelectric Investigations. Rafidain Journal of Science, 16 (6), 132-147.

Amos, M.J., 2007. Quasigeoid Modeling in New Zealand to Unify Multiple Local Vertical Datums. Curtin University of Technology, Department of Spatial Sciences, New Zealand, PhD thesis, 238 p.

Asgari, M., Mehramuz, M., 2015. Estimate the Crust Thickness using the Gravity Data for the KopehtDagh Region. Indian Journal of Science and Technology, 8 (9), 513-517.

Chen K.H., 2009. An Improved Approach for Terrain Correction: Application to Northeast Asia's
Highest Peak (Mt. Jade, Taiwan). Sensors (Basel), 9 (9), 6604-6612.

Dobrin, M.B., Savit, C.H., 1988. Introduction to Geophysical Prospecting: McGraw-Hill Book Company, $867 \mathrm{p}$.

Geosoft Oasis Montaj (GOM) reference manual, 2008. Software for Earth Sciences, Geosoft INC, Toronto, Canada.

Ghaib, F.A., Mohammad, R.J., Khan, Z.A., 1998. A reconnaissance gravity survey in the Sulaivany plain, N-Iraq. The Journal of Duhok University (Scientific and Academic), 1 (1): 6-20.

Hafidh A.A., Matthew S., Youlin Chen, Robert B., Ghassan I., Hrvoje T., Bakir S., Borhan I., Dawood S., Robert A., Patrick J., Omar K., Aras M., Shaho A., Fadhil I., Rashid Z., Basoz A., Layla O., Nokhsha I., Nian H., Talal N., Ali A., Abdul-Karem A., Samira R., 2007. Seismic velocity modeling of north and northeast Iraq using receiver functions, 29th Monitoring Research Review: Ground-Based Nuclear Explosion Monitoring Technologies.

Hernandez, O., 2006. Tectonic analysis of northwestern South America from integrated satellite, airborne and surface potential field anomalies. Graduate School of Ohio State University, U.S.A, PhD thesis, $176 \mathrm{p}$.

Hinze W.J., Aiken C., Brozena J., Coakley B., Dater D., Flanagan G., Forsberg R., Hildenbrand T., Keller G.R., Kellogg J., Kucks R., Li X., Mainville A., Morin R., Pilkington M., Plouff D., Ravat D., Roman D., Urrutia-Fucugauchi J., V'eronneau M., Webring M., Winester D., 2005. New standards for reducing gravity data, The North American gravity database. Geophysics, 70 (4), J25-J32.

Janák, J., Vanícek, P., 2005. Mean free-air gravity anomalies in the mountains. Studia Geophysia et Geodaetica, 49, 31-42.

Jassim, S.Z., Goff J.C., 2006. Phanerozoic development of the northern Arabian Plate, Geology of Iraq, 3244.

Leaman, D.E., 1998. The gravity terrain correctionpractical considerations. Exploration Geophysics, $29,476-471$.

Li, X., Götze, H.J., 2001. Ellipsoid, geoid, gravity, geodesy, and geophysics, Geophysics, 66, 16601668 . 
Lockwood, A., 2004. Isostatic and Decompensative Gravity Anomalies over Western Australia. Australian Society of Exploration Geophysicists, Preview, 108, 22-23.

Lowrie, W., 2007. Fundamentals of Geophysics. Cambridge University Press, Cambridge, UK, 354 p.

Lynch, A. and King, R.A., 1983. A review of parameters affecting the accuracy and resolution of gravity surveys. Exploration Geophysics, 14: 131-142.

Lyngsie, S.B., Thybo, H., Rasmussen, T.M., 2006. Regional geological and tectonic structures of the North Sea area from potential field modeling. Tectonophysics 413, 147-170.

Mogren, S., Al-Amri, A.S., Al-Damegh, K., Fairhead, D., Jassim, S., Algamdi, A., 2007. Sub-surface geometry of Ar Rika and Ruwah faults from Gravity and Magnetic Surveys, King Saud University, College of Sciences, Geology \& Geophysics Department, Riyadh, Saudi Arabia.

Mutib M., 1980. Geophysical investigation around Demir Dagh area. Mosul University, Iraq, MSc. thesis, (unpublished).
Nabighian, M.E., Ander, V.J., Graunch, R.O., Hansen, T.R., Lafehr, Y. Pearson, W.C., Peirce, J.W., Phillips, J.D., Ruder, M.E., 2005. Historical Development of the Gravity Method in Exploration. Geophysics, 70 (6), 63-89.

Roy, K.K., 2008. Potential Theory in Applied Geophysics. Springer-Verlag Berlin Heidelberg, $651 \mathrm{p}$.

Sayyab, A., Valek, R., 1968. Pattern and general properties of the gravity field of Iraq. $23^{\text {rd }}$ International Geological Congress, Czechoslovakia, 5, 129-142.

Zeng, H., Xu, D., Tan, H., 2007. A model study for estimating optimum upward continuation height for gravity separation with application to a Bouguer gravity anomaly over a mineral deposit, Jilin province, Northeast China. Geophysics, 72, 145-150. 